\title{
Expression of Transforming Growth Factor- $\beta$ and Tumor Necrosis Factor- $\alpha$ in the Plasma and Tissues of Mice with Lupus Nephritis
}

\author{
Koji Yamamoto and David J. Loskutoff \\ First Department of Internal Medicine (KY), Nagoya University School of Medicine, Nagoya, Japan; and Department \\ of Vascular Biology (DJL), The Scripps Research Institute, La Jolla, California
}

\begin{abstract}
SUMMARY: Although elevated levels of transforming growth factor- $\beta$ (TGF- $\beta$ ) and tumor necrosis factor- $\alpha$ (TNF- $\alpha$ ) have been implicated in renal disease, the tissue distribution and cellular localization of the induced cytokines is not well established. In this study, we investigated the expression of these cytokines during the progression of lupus nephritis in MRL Ipr/lpr mice. The concentration of both cytokines increased in the plasma of these animals in an age-dependent manner, and there was an age-dependent induction of TGF- $\beta$ and TNF- $\alpha$ mRNAs in their kidneys. Although the increase in TGF- $\beta$ mRNA was specific for the kidney, the increase in TNF- $\alpha$ mRNA was widespread and also could be demonstrated in the liver, lung, and heart. In situ hybridization analysis of renal tissues from the lupus-prone mice localized TGF- $\beta$ mRNA to the glomerulus, and more specifically, to resident glomerular cells and inflammatory cells infiltrating periglomerular spaces in the nephritic lesions. The signals for TNF- $\alpha$ mRNA were detected only in inflammatory cells and were distributed throughout the nephritic kidney. Plasminogen activator inhibitor-1 (PAI-1) is known to be elevated in the glomeruli of MRL Ipr/Ipr mice, and intraperitoneal administration of either TGF- $\beta$ or TNF- $\alpha$ into normal mice markedly induced the expression of this potent inhibitor of fibrinolysis in renal glomerular or tubular cells in vivo. These results suggest that the increased renal expression of both cytokines may contribute to the development of lupus nephritis in this model and raise the possibility that PAI-1 may be involved. The fact that TGF- $\beta$ is specifically induced in the kidney whereas TNF- $\alpha$ increases in a variety of tissues, supports the hypothesis that the renal specificity of this disorder reflects the abnormal expression of TGF- $\beta$. (Lab Invest 2000, 80:1561-1570).
\end{abstract}

\begin{abstract}
upus nephritis which often accompanies the auL toimmune disorder, systemic lupus erythematosus, is characterized by extracellular matrix accumulation and the formation of glomerular, tubular, vascular, and interstitial lesions (Hayslett and Kashgarian, 1993). Inflammatory and immunological processes have been implicated in the development of this nephropathy, including the elaboration of transforming growth factor- $\beta$ (TGF- $\beta$ ) and tumor necrosis factor- $\alpha$ (TNF- $\alpha$ ) (Border and Ruoslahti, 1992; Boswell et al, 1988; Brennan et al, 1989; Moll et al, 1995).

TGF- $\beta$ is a multifunctional cytokine that can either inhibit or stimulate cellular proliferation and, as such, seems to play a critical role in tissue repair and regeneration after injury (Border and Ruoslahti, 1992). This cytokine not only stimulates the synthesis of individual matrix components, including fibronectin (Ignotz and Massagu, 1986), collagens (Roberts et al, 1986), and proteoglycans (Bassols and Massagu, 1988; Border et al, 1990a), but it also blocks matrix degradation by decreasing the synthesis of proteases
\end{abstract}

Received July 20, 2000.

This work was supported by National Institutes of Health grant HL-47819 (DJL).

Address reprint requests to: Dr. K. Yamamoto, First Department of Internal Medicine, Nagoya University School of Medicine, 65 Tsurumai, Showa, Nagoya 466-8550, Japan. Fax: 8152744 2157; E-mail: kojiy@med.nagoya-u.ac.jp and by increasing the levels of protease inhibitors (Edwards et al, 1987; Laiho et al, 1987). Thus, the expression of TGF- $\beta$ may promote the deposition of extracellular matrix (Roberts et al, 1986) and the development of fibrosis (Border and Noble, 1994) in certain types of glomerulonephritis (Okuda et al, 1990), in lung fibrosis (Broekelmann et al, 1991), in liver cirrhosis (Czaja et al, 1989), in cardiac fibrosis after infarction (Thompson et al, 1988), and in scarring disorders of the eye (Connor et al, 1989) and skin (Shah et al, 1992). Elevated renal expression of TGF- $\beta$ has been demonstrated in experimental glomerulonephritis (Coimbra et al, 1991; Okuda et al, 1990) and in several types of human kidney disease (Yamamoto et al, 1993; Yamamoto et al, 1996; Yoshioka et al, 1993). TGF- $\beta$ is a potent inducer of antifibrinolytic (eg, plasminogen activator inhibitor-1: PAI-1) (Sawdey and Loskutoff, 1991) and procoagulant (tissue factor: TF) (Ranganathan et al, 1991) gene expression in the kidney. However, in spite of the link between TGF- $\beta$ and kidney disease, little is known about the cellular distribution of the genes induced by TGF- $\beta$ during the progression of kidney disease, and the cellular localization of TGF- $\beta$ itself in renal pathologies in vivo has not been fully elucidated.

Although TNF- $\alpha$ is an important regulator of the immune response, alterations in TNF- $\alpha$ also have been implicated in kidney diseases (Boswell et al, 1988; Neale et al, 1995). This cytokine is produced primarily 
by cells of the monocyte/macrophage lineage, although a wide range of cell types have been reported to express it as well (Tracey and Cerami, 1994). It has been suggested that the local expression of TNF- $\alpha$ during the inflammatory response may modulate the synthesis of hemostatic genes by endothelial cells (Clauss et al, 1992). Although TNF- $\alpha$ has been reported to promote a procoagulant/antifibrinolytic profile when administered to cells in vitro (Sawdey et al, 1989; Scarpati and Sadler, 1989; Schleef et al, 1988), there is little information available regarding the induction of hemostatic genes by TNF- $\alpha$ in the kidney in vivo (Sawdey and Loskutoff, 1991). In human and animal renal diseases, TNF- $\alpha$ expression is associated predominantly with extrinsic inflammatory cells (Matsumoto, 1993; Noronha et al, 1993), and elevated levels of TNF- $\alpha$ mRNA and antigen in the renal cortex were detected in lupus-prone mice (Brennan et al, 1989; Yokoyama et al, 1995). In contrast, TNF- $\alpha$ was shown to protect the NZB $x$ NZW F1 hybrid from developing lupus nephritis (Jacob and McDevitt, 1988). Thus, because of the multiplicity of its effects, the exact contribution of TNF- $\alpha$ to the development of lupus nephritis remains unclear.

To begin to evaluate the potential pathological role of TGF- $\beta$ and TNF- $\alpha$ in autoimmune lupus nephritis, we compared the expression of these cytokines in the plasma and tissues of mice with lupus nephritis (MRL Ipr/lpr) with that of their control counterparts (MRL $+/+)$. We also determined the ability of TGF- $\beta$ and TNF- $\alpha$ to induce PAl-1 mRNA expression in the kidneys because previous studies implicate PAl- 1 in the progression of lupus nephritis in MRL Ipr/lpr mice (Keeton et al, 1995). Although both cytokines increased with age in the plasma of diseased animals (ie, as a function of disease progression), TGF- $\beta$ mRNA was specifically increased in the kidney of the lupus-prone mice, whereas the induction of TNF- $\alpha$ mRNA occurred in several tissues, including the kidney, liver, lung, and heart. Both cytokines also induced the expression of PAl-1 (Sawdey et al, 1989; Sawdey and Loskutoff, 1991), the principal inhibitor of plasminogen activation, in the normal murine kidney in vivo. The increase in PAl-1 may decrease local fibrinolytic potential in the kidney and promote fibrin formation and renal injury (Tsumagari and Tanaka, 1984), two conditions frequently detected in lupus-nephritic lesions (Kant et al, 1981, 1985). The specific induction of TGF- $\beta$, but not TNF- $\alpha$, in the kidney may contribute to the progression of lupus nephritis by promoting extracellular matrix accumulation and fibrin deposition. The more widespread induction of TNF- $\alpha$ suggests that it may play a pathological role in autoimmune diseases through the stimulation of systemic inflammatory responses and the alteration of hemostatic balance in vascular cells.

\section{Results}

\section{TGF- $\beta$ Antigen and TNF- $\alpha$ Activity Levels in Plasma from Lupus-Prone Mice}

Figure 1 shows the levels of TGF- $\beta$ antigen and TNF- $\alpha$ activity in plasma from lupus-prone mice of different ages compared with the levels in control mice. No difference in total TGF- $\beta$ antigen levels was detected in plasma from 2-month-old control and lupus-prone mice. However, a 2 -fold increase in TGF- $\beta$ antigen was observed in plasma from 5-month-old lupusprone mice compared with controls, and a 1.5-fold increase was observed in 6-month-old lupus-prone mice compared with controls (Fig. 1A). Similar agerelated increases (2- to 3-fold) in TNF- $\alpha$ activity were observed in plasma from 5- to 6-month-old lupusprone mice compared with control mice (Fig. 1B).

\section{TGF- $\beta$ and TNF- $\alpha$ mRNA Levels in Tissues from Lupus-Prone Mice}

We next compared the expression of TGF- $\beta$ and TNF- $\alpha$ mRNAs in tissues from control and lupus-prone
A

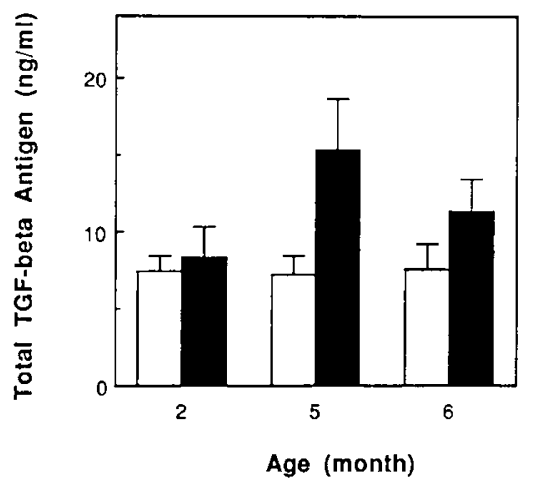

B

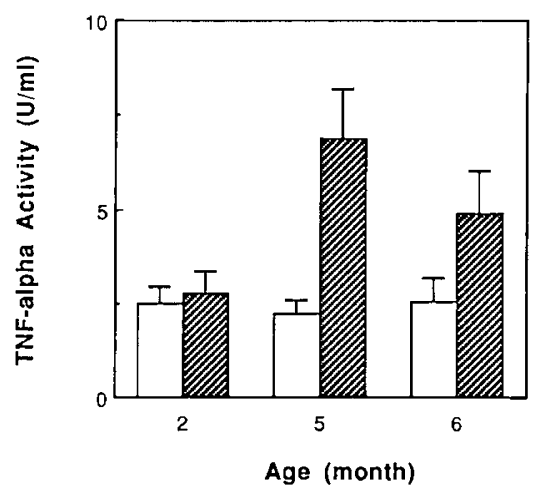

Figure 1.

Age-related changes in transforming growth factor (TGF)- $\beta$ antigen and tumor necrosis factor (TNF)- $\alpha$ activity in plasma from control and lupus-prone mice. Plasma was collected from mice of different ages and analyzed for TGF- $\beta$ antigen and TNF- $\alpha$ activity as described in the "Materials and Methods" section. $A$, TGF- $\beta$ antigen levels from control (open columns) and lupus-prone (closed columns) mice. B, TNF- $\alpha$ activity from control (open columns) and lupus-prone (hatched columns) mice. The data are expressed as the mean and SD obtained using five mice in each category. For TGF- $\beta$ antigen, $p<0.03$ for 5-month-old and $p<0.05$ for 6 -month-old control vs lupus-prone mice. For TNF- $\alpha$ activity, $p<0.02$ for 5 -month-old and $p<0.03$ for 6 -month-old control vs lupus-prone mice. 
mice using quantitative reverse transcription (RT)-PCR assays. A dramatic, age-related increase in TGF- $\beta$ mRNA was observed in the kidney from lupus-prone mice compared with the normal kidney (Fig. 2). For example, no significant differences in TGF- $\beta$ expression were observed when the kidneys of these mice were compared at 2 months. However, a 2-fold increase in the relative levels of TGF- $\beta$ mRNA was apparent in kidneys from lupus-prone mice by 3 months, a time in which the onset of obvious disease was not yet observed by microscopic examination (Keeton et al, 1995). Marked increases in TGF- $\beta$ mRNA levels also were apparent in diseased kidneys with lupus-like nephritic changes (eg, 2.5-fold increase at 4 months, 3.4-fold at 5 months, and 2.5 -fold at 6 months). Thus, this increase in renal TGF- $\beta$ mRNA was age-related and occurred in parallel with the development of lupus glomerulonephritis (Moll et al, 1995; Theofilopoulos and Dixon, 1985). The increases in TGF- $\beta$ mRNA were relatively specific for the diseased kidney because we were unable to detect significant increases in TGF- $\beta$ expression in most other organs examined at any age, including the heart, liver, lung, brain, and spleen (Fig. 2). No specific pathological changes were detected in these tissues at any age except for the infiltration of inflammatory cells with occasional expression of TGF- $\beta$ mRNA detected by in situ hybridization (data not shown).

Significant age-related increases in TNF- $\alpha$ mRNA also were detected in the kidney from lupus-prone mice (Fig. 3). However, in contrast to the results with TGF- $\beta$, increased expression of TNF- $\alpha$ mRNA was not restricted to the diseased kidney. In fact, marked elevations in TNF- $\alpha$ mRNA were detected in the liver, lung, and heart from 4- to 6-month-old lupus-prone mice. No significant differences in TNF- $\alpha$ mRNA levels were detected in the brain and spleen from control and diseased mice at any age.

\section{Localization of TGF- $\beta$ and TNF- $\alpha$ mRNAs in Tissues from Lupus-Prone Mice}

Regional in situ autoradiography of kidneys from 5-month-old mice showed markedly enhanced accumulation of TGF- $\beta$ mRNA in the diseased renal cortex (Fig. 4, compare panels $A$ and $B$ ). The distinctive speckled pattern in the cortex suggests a glomerular localization, and this hypothesis is supported by the results shown in Figure 5. For example, high resolution in situ analysis of the kidney failed to detect a specific signal for TGF- $\beta$ mRNA in glomeruli or in tubular and perivascular regions in control kidneys (Fig. 5A). However, in kidneys from lupus-prone mice, increased TGF- $\beta$ mRNA was apparent in resident glomerular cells (eg, mesangial cells; Fig. 5B) and in infiltrating inflammatory cells (eg, macrophages) in periglomerular regions (Fig. 5C). Mononuclear cells infiltrating peritubular (Fig. 5D) and perivascular (Fig. 5E) regions also expressed abundant TGF- $\beta$ mRNA in the lupus nephritis. The blue color characteristic of our hybrid-
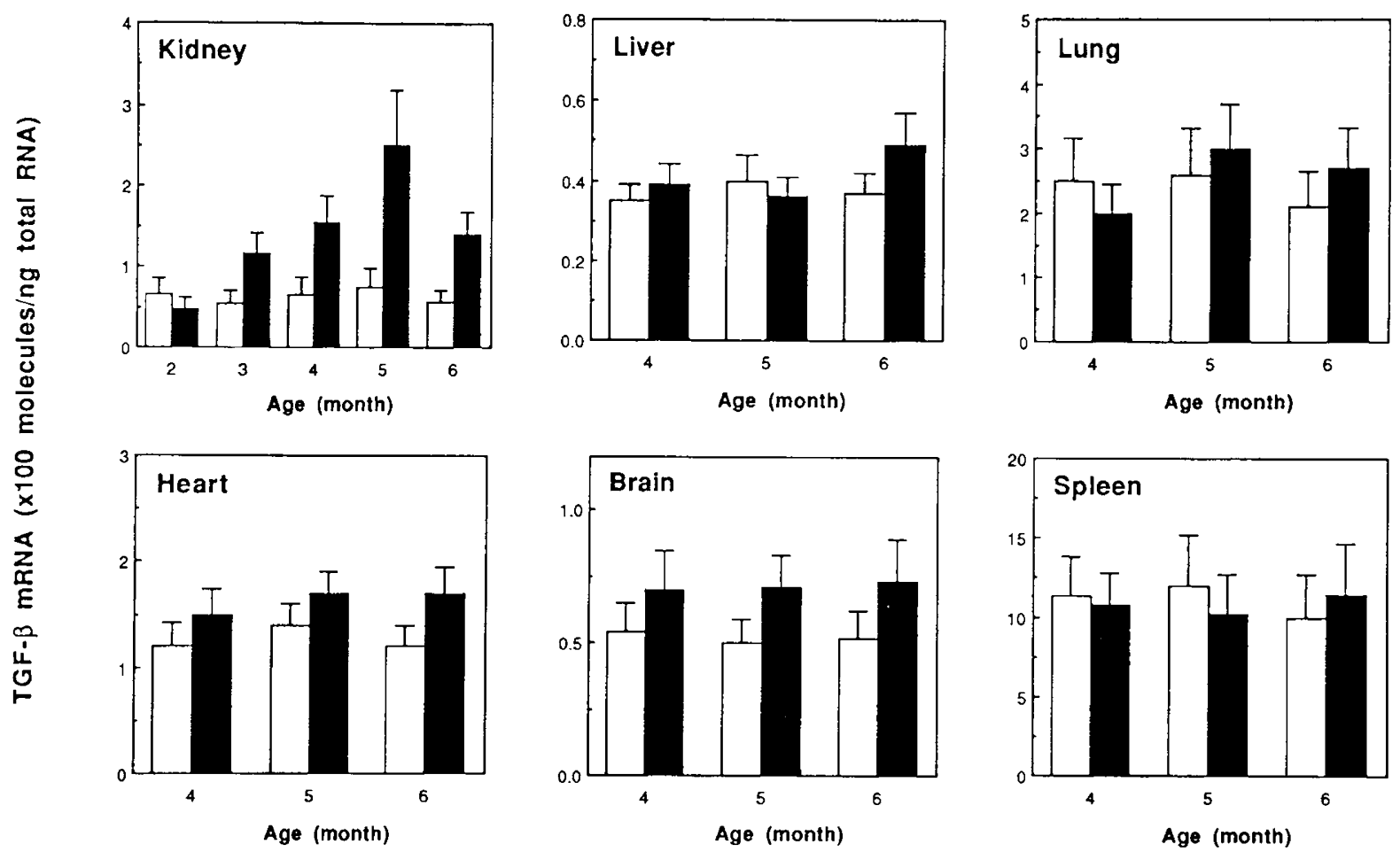

Figure 2.

Age-related changes in TGF- $\beta$ mRNA in tissues from control and lupus-prone mice. The indicated tissues were harvested from lupus-prone (black columns) and control (white columns) mice at various ages. Total RNA was prepared and analyzed for TGF- $\beta$ mRNA by quantitative reverse transcription-polymerase chain reaction (RT-PCR) as described in the "Materials and Methods" section. The data are expressed as the mean and SD obtained using five mice in each category. For the TGF- $\beta$ mRNA levels in the kidney, $p<0.03$ for 3-month-old, $p<0.03$ for 4 -month-old, $p<0.008$ for 5 -month-old, and $p<0.02$ for 6 -month-old control vs lupus-prone mice. 

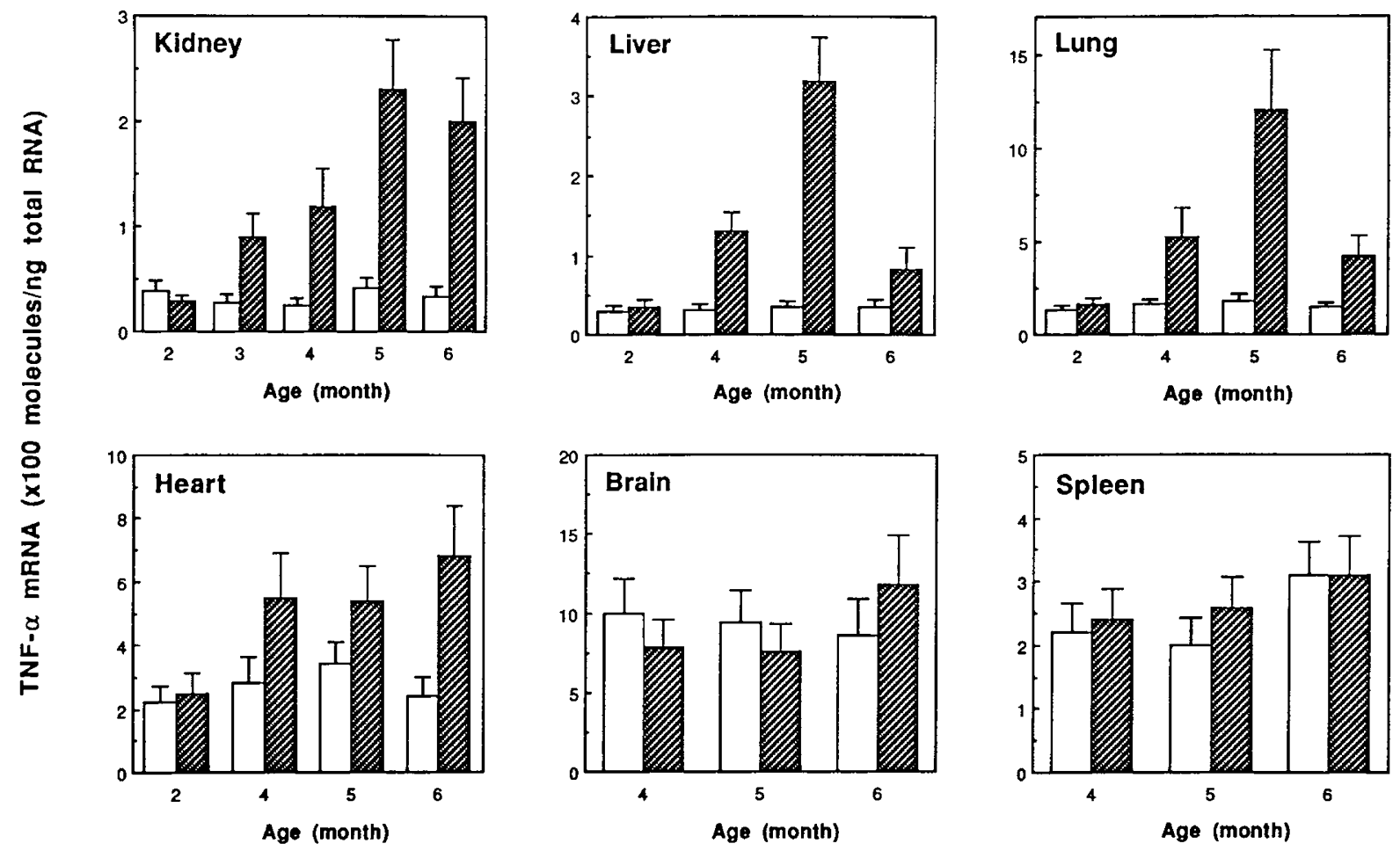

Figure 3.

Age-related changes in TNF- $\alpha$ mRNA in tissues from control and lupus-prone mice. Total RNA was prepared from tissues of control (white columns) and lupus-prone (hatched columns) mice, and analyzed for TNF- $\alpha$ mRNA by quantitative RT-PCR as described in the "Materials and Methods" section. The data are expressed as the mean and SD obtained using five mice in each category. The $p$ values for control vs lupus-prone mice at 5 months of age were $p<0.002$, kidney; $p<0.001$, liver; $p<0.002$, lung; $p<0.05$, heart.

ization signal using indirect illumination in this system is not always even over the slide. Thus, the white dots in Figure 5 are also specific hybridization signals that have been bleached out in the photograph.

Regional in situ autoradiography for TNF- $\alpha$ mRNA in kidneys from 5-month-old MRL Ipr/lpr mice revealed a different pattern than that observed for TGF- $\beta$ mRNA. In this case, the increased hybridization signal was not confined to glomerular structures but rather was distributed throughout the kidney (Fig. 4, compare panels $C$ and D). This observation suggests that TNF- $\alpha$ mRNA was expressed in inflammatory cells in the nephritic kidney and not in resident glomerular cells. High resolution in situ hybridization analysis of the kidney from lupus-prone mice supports this possibility. For example, although no hybridization signal for TNF- $\alpha$ mRNA was detected in the control kidney (Fig. $5 F)$, positive specific signals were localized to clusters of inflammatory cells infiltrating in periglomerular, peritubular, and perivascular regions (Fig. 5, G to I). Resident cells inside glomeruli in the nephritic kidney were, in general, negative (Fig. 5l).

\section{Effects of TGF- $\beta$ and TNF- $\alpha$ on the Renal Expression of PAl-1 in the Normal Mouse}

Because we previously observed the dramatic induction of PAl-1 in renal tissues with fibrin deposition during the development of lupus nephritis in MRL Ipr/lpr mice (Yamamoto and Loskutoff, 1997), the contributive effect of TGF- $\beta$ or TNF- $\alpha$ on the induction of PAl-1 in the normal murine kidney was further examined in this study. Renal tissues of adult CB6 mice were harvested at 3 hours after intraperitoneal injection with TGF- $\beta$, TNF- $\alpha$, or saline alone; total RNA was prepared for quantitative RT-PCR; and tissue sections were prepared for in situ hybridization. Both cytokines dramatically induced PAI-1 mRNA (20-fold by TGF- $\beta$ and 15 -fold by TNF- $\alpha$ ) in the kidney (Table 1 ). Regional in situ autoradiography of renal tissues from mice injected with TGF- $\beta$ demonstrated relatively high levels of PAI- 1 mRNA in the inner medulla and papilla, with positive signals also distributed to glomerular structures in the cortex (Fig. 6B). No specific signals for PAl-1 mRNA were detected in the control kidney (Fig. 6A). In contrast to these results, TNF- $\alpha$ induced PAI-1 mRNA primarily in the glomerular structure in the renal cortex (Fig. 6C). High resolution in situ analysis of renal tissues from control mice again failed to detect a specific signal for PAl-1 mRNA (Fig. 6D). However, in the kidneys of mice injected with TGF- $\beta$, elevated PAl-1 mRNA was detected in glomerular mesangial cells, Bowmann's capsular epithelial cells, vascular smooth muscle cells, inflammatory mononuclear cells (Fig. 6E), and in tubular epithelial cells in collecting tubules and papillary ducts in the medulla (Fig. 6F). PAI-1 mRNA was not detected in endothelial cells. In TNF- $\alpha$-treated mice, increased signals for PAl-1 mRNA were localized to cells that appear to be glomerular and peritubular endothelial cells (Fig. 6G). 


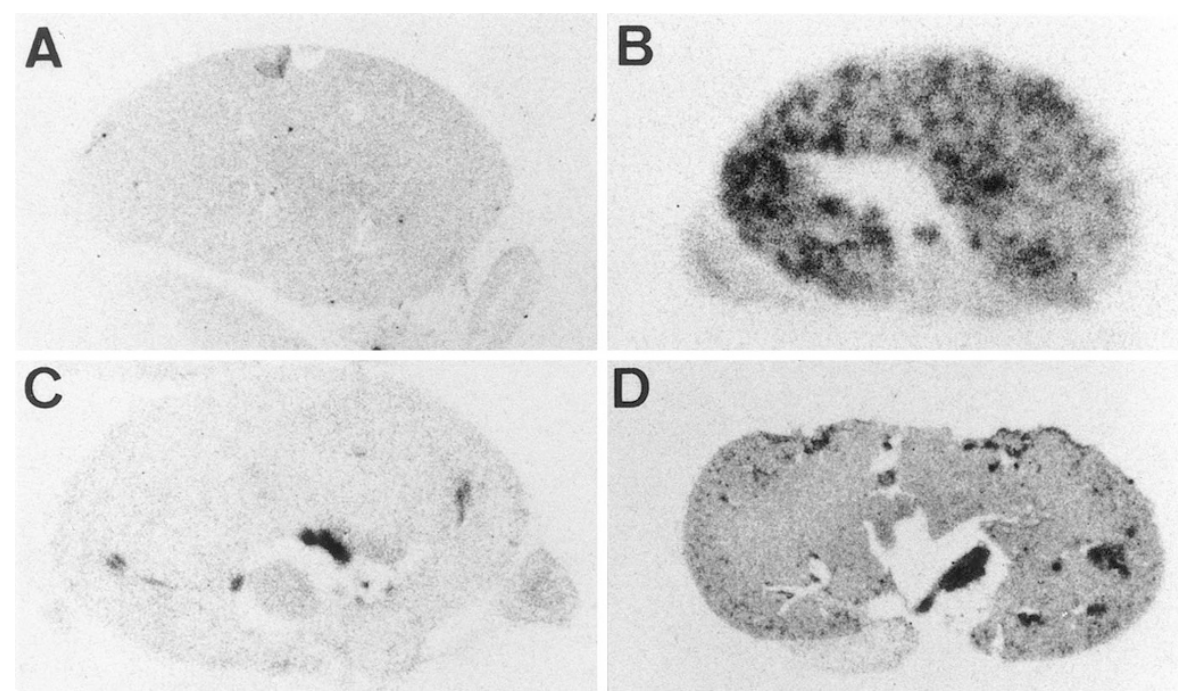

Figure 4.

Regional localization of TGF- $\beta$ and TNF- $\alpha$ mRNA in kidney sections from control and lupus-prone mice. Kidney sections from 5-month-old control MRL $+/+(A$ and $C)$ and diseased MRL Ipr/Ipr $(B$ and $D)$ mice were analyzed by regional in situ autoradiography as described in the "Materials and Methods" section. The sections were incubated on X-ray film and photographed after 2 weeks' exposure at room temperature. Hybridization signals are indicated by the black grains in the photographs. $A$ and $B$ show the distribution of TGF- $\beta$ mRNA, whereas $C$ and $D$ show TNF- $\alpha$ mRNA.

\section{Discussion}

In this study, we attempt to relate changes in the pattern of TGF- $\beta$ and TNF- $\alpha$ gene expression to the progression of lupus nephritis using MRL Ipr/lpr mice as models. Because both cytokines have been reported to induce PAl-1 gene expression (Sawdey and Loskutoff, 1991; Sawdey et al, 1989), and because PAI-1 was previously correlated to the progression of lupus nephritis in MRL Ipr/lpr mice (Keeton et al, 1995; Yamamoto and Loskutoff, 1997), we also examined the ability of these cytokines to induce renal PAI-1. These studies were initiated because increased renal expression of both cytokines frequently correlates with the disease state. For example, elevated expression of TGF- $\beta$ was demonstrated in glomerular cells in experimental glomerulonephritis (Coimbra et al, 1991; Okuda et al, 1990) and in several human glomerular diseases, including diabetic nephropathy (Yamamoto et al, 1993), IgA nephritis, proliferative glomerulonephritis (Yoshioka et al, 1993), crescentic glomerulonephritis, and lupus nephritis (Yamamoto et al, 1996). Moreover, administration of TGF- $\beta$ promotes the pathological accumulation of extracellular matrix (Border and Ruoslahti, 1992) and tissue fibrosis in the kidney (Border and Noble, 1994; Roberts et al, 1986) and plays a role in expansion of the mesangial extracellular matrix (Okuda et al, 1990; Tomooka et al, 1992). Administration of a neutralizing antibody to TGF- $\beta$ decreases glomerular accumulation of extracellular matrix (Border et al, 1990b). These results suggest that the induction of TGF- $\beta$ may be relevant to the progression of glomerular disease. However, despite this strong correlation between TGF- $\beta$ and renal disease, the exact distribution of TGF- $\beta$ in diseased kidneys remains to be determined. We detected elevated TGF- $\beta$ antigen in plasma from aged lupus- prone mice (Fig. 1). Quantitative RT-PCR (Fig. 2) and in situ hybridization experiments (Figs. 4 and 5) suggest that glomerular cells and infiltrating inflammatory cells in the nephritic kidney contribute to the observed increased plasma TGF- $\beta$ levels. However, it is also possible that inflammatory cells recruited to other tissues (eg, liver or spleen) secret considerable amounts of TGF- $\beta$ in this model (Caver et al, 1996). The observation that the accumulation of TGF- $\beta$ mRNA in the lupus-prone mice was localized to the kidneys (Fig. 2) and, more specifically, to the glomerular structures within them, in which the histopathological changes of lupus nephritis were most pronounced (Fig. 4), suggests that this TGF- $\beta$ may contribute to the tissue-specific pathology in this model (Kreft et al, 1996).

The exact contribution of TNF- $\alpha$ to the progression of lupus nephritis is less clear because previous studies of TNF- $\alpha$ expression in renal cells under physiological and pathological conditions (Noronha et al, 1993; Tovey et al, 1988) produced conflicting results. For example, a correlation between TNF- $\alpha$ expression and the pathogenesis of experimental nephropathy was demonstrated in rats (Gomez-Chiarri et al, 1994) and in the development of human membranous nephropathy (Neale et al, 1995). Similarly, elevated renal expression of TNF- $\alpha$ and interleukin-1 correlated with the severity of renal injury in murine lupus nephritis (Brennan et al, 1989). In contrast, peritoneal macrophages from lupus-prone mice (NZB x NZW F1) produced lower levels of TNF- $\alpha$ than controls, and injection of TNF- $\alpha$ into these mice protected them from developing lupus nephritis (Jacob and McDevitt, 1988). Here we show that the induction of TNF- $\alpha$ mRNA during the progression of lupus nephritis is not restricted to the kidney as was the case for TGF- $\beta$ 

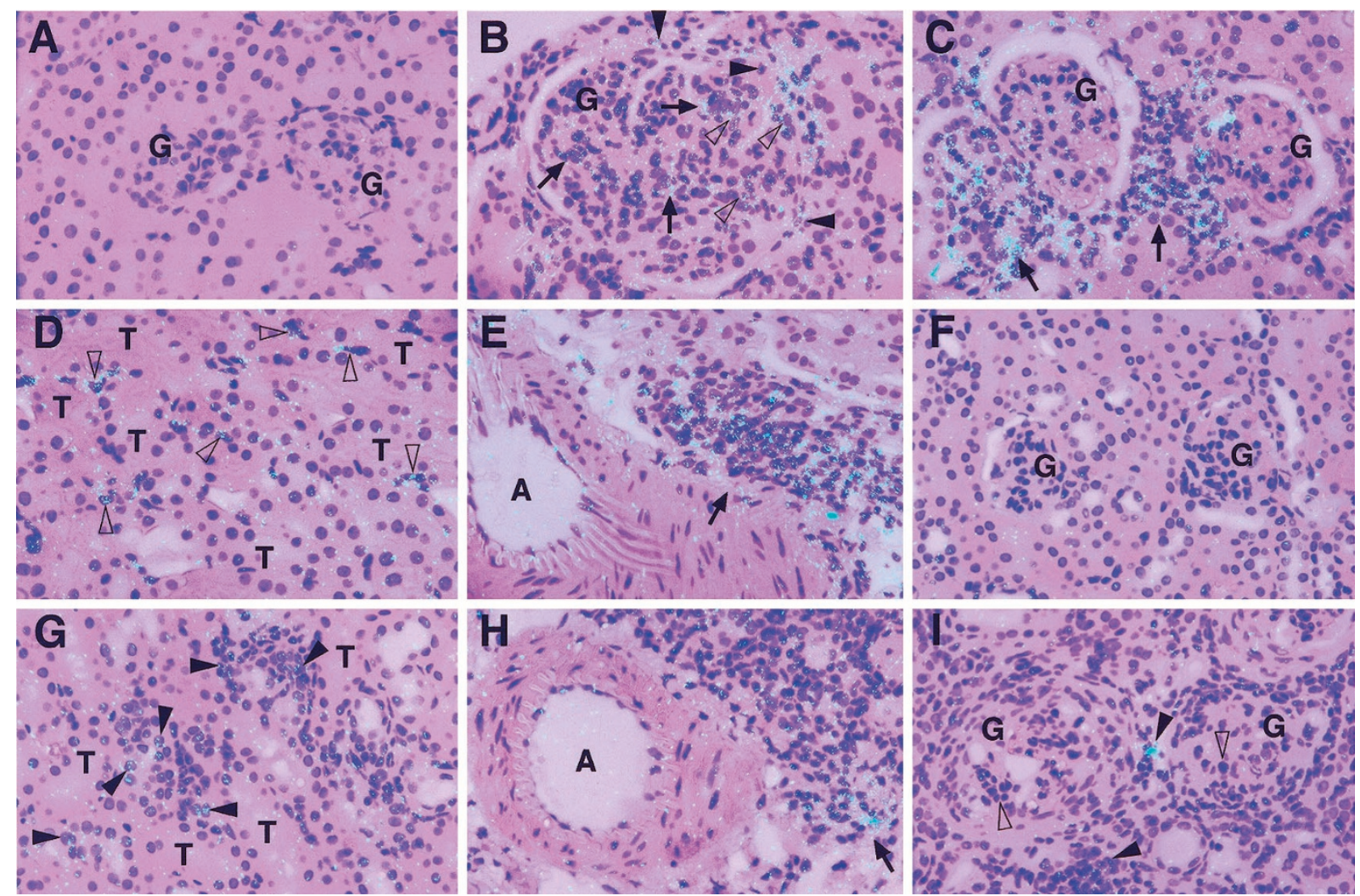

Figure 5.

High-resolution in situ hybridization analysis of TGF- $\beta$ and TNF- $\alpha$ mRNA in kidneys from control and lupus-prone mice. Kidney sections from 5-month-old MRL Ipr/lpr (lupus-prone) and MRL +/+ mice (control) were hybridized to the ${ }^{35}$ S-labeled TGF- $\beta$ (Panels $A$ to $E$ ) or TNF- $\alpha$ (Panels $F$ to $I$ ) riboprobe and analyzed as described in the "Materials and Methods" section. Panels $A$ to $C$, Renal glomeruli $(G)$ from a control mouse (Panel $A)$ and from a lupus-prone mouse (Panels $B$ and $C), \times 400$. In Panel B, closed arrowheads denote parietal epithelial cells, open arrowheads indicate resident glomerular cells, and arrows show macrophages inside the glomerulus. Arrows in Panel $C$ indicate clusters of infiltrating inflammatory cells in periglomerular regions. Panel $D$ indicates tubular $(T)$ regions in the renal cortex from a lupus-prone mouse $(\times 400)$. Open arrowheads in Panel $D$ denote what appear to be inflammatory mononuclear cells infiltrating peritubular regions. Panel $E$, Renal periarterial regions from a lupus-prone mouse $(\times 400)$. An arrow indicates a cluster of infiltrating inflammatory cells. $(A)$ Renal artery. Panel $F$ shows glomerul (G) from a control mouse $(\times 400)$. Panel $G$ indicates tubular $(T)$ regions in the renal cortex $(\times 400)$ and Panel $H$ shows the renal periarterial region $(\times 400)$, both from a lupus-prone mouse. Closed arrowheads in Panel $G$ denote inflammatory cells infiltrating peritubular regions and an arrow in Panel $H$ indicates a cluster of inflammatory cells infiltrating the periarterial region. $(A)$ Renal artery. Panel I indicates glomerular regions from a lupus-prone mouse $(\times 400)$. Open arrowheads denote cells that appear to be resident glomerular cells and closed arrowheads indicate cells that resemble inflammatory cells infiltrating periglomerular regions. Slides for Panels $A$ to $E$ were exposed for 10 weeks and slides for Panels $F$ to / exposed for 12 weeks at $4^{\circ} \mathrm{C}$.

(Fig. 2). Instead, TNF- $\alpha$ mRNA was elevated in many organs besides the kidney, including the liver, lung, and heart (Fig. 3). Moreover, unlike the increase in TGF- $\beta$ mRNA, the increase in TNF- $\alpha$ mRNA was not associated with specific glomerular cells, but rather was localized to infiltrating inflammatory cells and distributed throughout the lupus-nephritic kidney (Fig. 4). The widespread induction of TNF- $\alpha$ mRNA in tissues that show no signs of disease suggests that TNF- $\alpha$ alone is not sufficient to promote the extracellular matrix accumulation and fibrosis associated with this disorder. Our preliminary observation that TNF- $\alpha$ is a potent inducer of TGF- $\beta$ expression in the kidney in vivo (Yamamoto and Loskutoff, unpublished observation) raises the possibility that TNF- $\alpha$ may also contribute to the development of glomerulonephritis through the induction of renal TGF- $\beta$.

TNF- $\alpha$ may also mediate the recruitment of mononuclear infiltrates (Matsumoto, 1993) and thus contribute to the vasculitis associated with the formation of thrombi. The observation that TNF- $\alpha$ is able to recruit macrophages and alter the hemostatic and/or fibrinolytic properties of cells (Sawdey et al, 1989; Scarpati and Sadler, 1989; Schleef et al, 1988) makes it likely

Table 1. Effects of TGF- $\beta$ and TNF- $\alpha$ on the Expression of PAl-1 mRNA in the Normal Murine Kidney ${ }^{a}$

\begin{tabular}{lccc}
\hline & Saline & TGF- $\beta$ & TNF- $\alpha$ \\
\hline PAl-1 mRNA $^{b}$ & $0.14 \pm 0.07$ & $2.8 \pm 0.73$ & $2.1 \pm 0.64$ \\
Fold induction & NA & 20 & 15 \\
\hline
\end{tabular}

TGF- $\beta$, transforming growth factor- $\beta$; TNF- $\alpha$, tumor necrosis factor- $\alpha$ PAI-1, plasminogen activator inhibitor-1.

${ }^{a}$ Adult CB6 mice were injected intraperitoneally with either $2 \mu \mathrm{g} \mathrm{TGF}-\beta, 4$ $\mu \mathrm{g}$ TNF- $\alpha$, or saline alone. The animals were killed 3 hours later, the kidneys were removed, and renal RNA was prepared.

${ }^{b}$ The concentration of PAl-1 mRNA in the kidney was determined by quantitative RT-PCR and the data are presented as $\times 10^{6}$ molecules of PAl- 1 $\mathrm{mRNA} / \mu \mathrm{g}$ total RNA (mean and sD for three independent experiments from three adult CB6 mice). The fold-induction values were calculated by direct comparison to the PAl-1 mRNA concentration in the kidney treated with saline. NA, not applicable. 

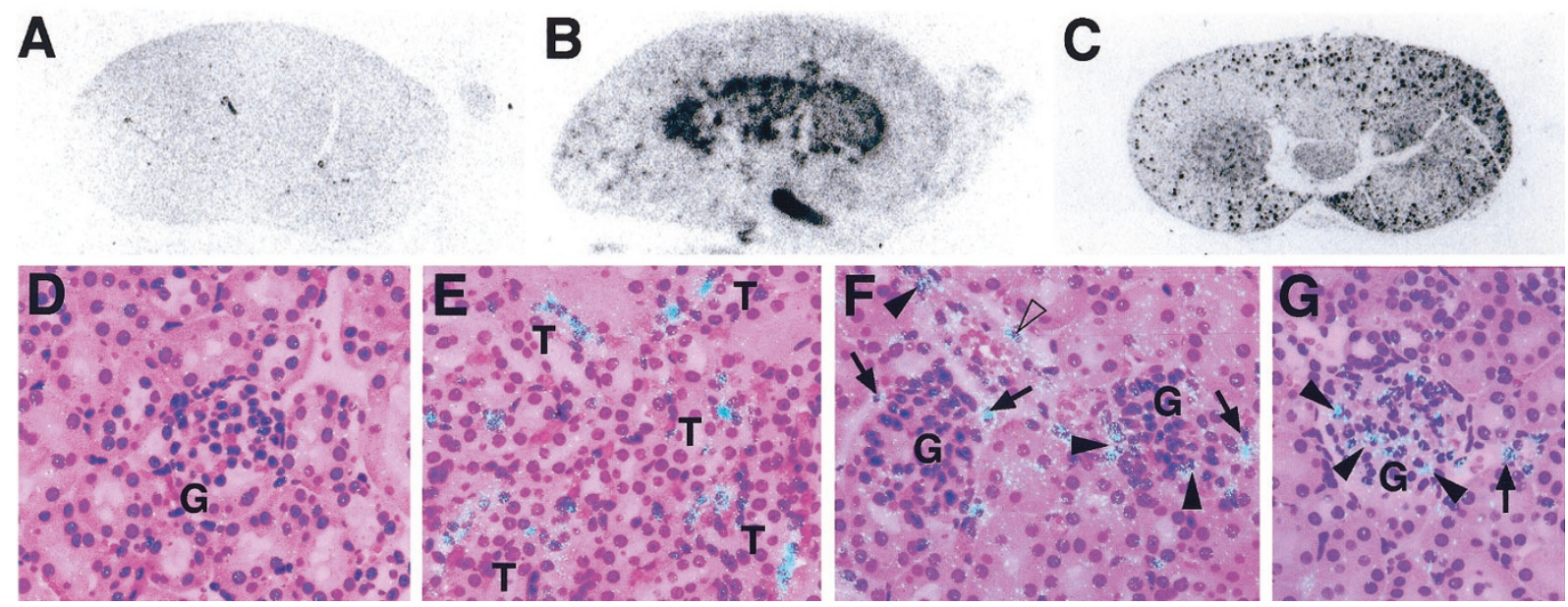

Figure 6.

In situ hybridization analysis of PAl-1 mRNA induced by TGF- $\beta$ or TNF- $\alpha$ in kidneys. Kidneys were harvested from CB6 mice at 3 hours after injection with either TGF- $\beta$ (Panels B, E, and $F$ ), TNF- $\alpha$ (Panels $C$ and $G$ ), or saline alone (Panels $A$ and $D$ ). The sections were hybridized to the ${ }^{35}$-labeled PAl-1 riboprobe and analyzed by regional in situ autoradiography (Panels $A$ to $C$ ) or by high-resolution in situ hybridization (Panels $D$ to $G$ ). Panels $D$, $F$, and $G$ show glomerular regions in the renal cortex $(\times 400)$, and Panel $E$ indicates the tubular region in the renal papilla $(\times 400)$. G, glomeruli; $T$, tubules. In Panel $F$, arrows denote positive parietal epithelial cells, closed arrowheads indicate inflammatory mononuclear cells, and the open arrowhead shows what appears to be a smooth muscle cell in a small artery. In Panel $G$, the arrow denotes what appears to be a peritubular endothelial cell, whereas arrowheads indicate cells that resemble glomerular endothelial cells. The sections for Panels $A$ to $C$ were incubated on X-ray film for 2 weeks. Slides for Panels $D$ to $G$ were exposed for 8 weeks at $4^{\circ} \mathrm{C}$.

that both TNF- $\alpha$ and TGF- $\beta$ contribute to lupus nephritis and fibrin deposits observed in this model (Kant et al, 1981). Studies of PAl-1 support this hypothesis. For example, examination of renal tissue from mice with lupus nephritis by in situ hybridization revealed increased $\mathrm{PAl}-1$ mRNA in infiltrating inflammatory cells in the glomeruli, in glomerular mesangial cells, and in endothelial cells (Keeton et al, 1995). PAl-1 mRNA was not detected in glomeruli under normal physiological conditions (Keeton et al, 1993), suggesting that this increase in PAl-1 may be mediated by cytokines locally released by these infiltrating inflammatory cells and/or by activated glomerular cells.

TGF- $\beta$ induces the expression of PAl- 1 in vitro (Pepper et al, 1991; Sawdey et al, 1989) and in vivo (Sawdey and Loskutoff, 1991; Wilson et al, 1993), and this induction is most pronounced in kidneys and adipose tissues in the mouse (Sawdey and Loskutoff, 1991). Moreover, addition of TGF- $\beta$ to cultured rat glomeruli also dramatically increased PAl-1 synthesis and markedly reduced plasminogen activator activity (Tomooka et al, 1992). It is noteworthy that the increased renal expression of TGF- $\beta$ mRNA in glomerular cells and infiltrating inflammatory cells occurred in parallel with the induction of PAl-1 mRNA in the lupus-nephritic kidney (Moll et al, 1995). We show that intraperitoneal administration of TGF- $\beta$ dramatically induced PAI-1 mRNA in the normal kidney (Table 1), and that the induced PAI-1 mRNA was localized to glomerular cells and tubular epithelial cells in the inner medulla and papilla (Fig. 6). Although TNF- $\alpha$ also markedly induced PAI-1 mRNA in glomerular structures in the normal kidney (Table 1, Fig. 6), this increase differed from that mediated by TGF- $\beta$ because it was localized primar- ily to endothelial cells (van Hinsbergh et al, 1988). This specific induction of PAl-1 mRNA in endothelial cells may account for the antifibrinolytic/procoagulant effects of TNF- $\alpha$ (Clauss et al, 1992). In any case, it seems likely that both TGF- $\beta$ and TNF- $\alpha$ contribute to the increased $\mathrm{PAI}-1$ in this model because the combined pattern of PAl-1 mRNA induction by these cytokines (Fig. 6) resembles the pattern in the kidneys of mice with lupus nephritis (Keeton et al, 1995; Yamamoto and Loskutoff, 1997). The increase in PAl-1 will not only inhibit proteolysis and increase the accumulation of extracellular matrix, but it may also lead to increased local procoagulant potential. Such changes are expected to promote glomerulosclerosis and fibrosis.

In conclusion, the observations in this study demonstrate a correlation between the increased renal expression of TGF- $\beta$ and TNF- $\alpha$, both of which can induce renal PAl-1 and the development of lupus nephritis. These observations raise the possibility that TGF- $\beta$ and PAI- 1 may contribute to the renal pathology because both have been reported to stimulate extracellular matrix accumulation (Okuda et al, 1990; Roberts et al, 1986; Vassalli et al, 1991) and promote sclerotic and fibrotic changes (Barnes et al, 1995; Border and Noble, 1994; Eitzman et al, 1996). It is also possible that the increased expression of TNF- $\alpha$ in the kidney may influence disease progression in this model (Brennan et al, 1989; Jacob and McDevitt, 1988). However, despite these considerations, the causative role of these molecules in the development of lupus nephritis remains to be demonstrated. To more directly address the role of these molecules in the development of this disorder will require the analysis of the progression of this disease in mice deficient in TGF- $\beta$, TNF- $\alpha$, or PAl-1. 


\section{Materials and Methods}

\section{Tissue Preparation}

Female MRL Ipr/lpr and control (MRL +/+) mice, aged 2 to 6 months (Scripps Clinic Rodent Breeding Colony, La Jolla, California), were killed by overdose inhalation anesthesia using metofane. The blood was collected into $20 \mathrm{mM}$ EDTA (final concentration) and centrifuged at $3000 \times g$ for 5 minutes, and then the plasma was removed and stored at $-70^{\circ} \mathrm{C}$. Tissues were rapidly removed by standard dissection techniques and either minced and immediately frozen in liquid nitrogen for preparation of total RNA or fixed overnight in chilled $4 \%$ paraformaldehyde and then embedded in paraffin for in situ hybridization. In some experiments, 2-month-old male CB6 mice were injected intraperitoneally with recombinant human TGF- $\beta$ (2 $\mu \mathrm{g} / \mathrm{mouse}$; Sigma Chemical Company, St. Louis, Missouri) or with recombinant murine TNF- $\alpha$ ( $4 \mu \mathrm{g} /$ mouse; a kind gift of Dr. Richard Ulevitch, The Scripps Research Institute), each diluted in a final volume of $200 \mu$ l of saline (Baxter, Deerfield, Illinois). Control CB6 mice were injected with an equivalent volume of saline alone. Three hours later, tissues were removed and processed as described above.

\section{Determination of TGF- $\beta$ Antigen and TNF- $\alpha$ Activity in Plasma}

Total TGF- $\beta$ antigen in plasma $(\mathrm{ng} / \mathrm{ml})$ was measured by ELISA using the TGF- $\beta 1$ KIT (Genzyme Corporation, Cambridge, Massachusetts), as previously described (Grainger et al, 1995). TNF- $\alpha$ activity in plasma $(\mathrm{U} / \mathrm{ml})$ was determined by employing the WEHI 164 clone 13 assay as previously described (Espevik and Nissen-Meyer, 1986).

\section{Quantitative RT-PCR}

A quantitative RT-PCR approach was employed to determine the concentration of specific mRNAs in murine tissues (Platzer et al, 1992; Yamamoto and Loskutoff, 1996). Competitive RT-PCR was performed using $10^{5}$ molecules of competitor RNA (cRNA) for TGF- $\beta$, TNF- $\alpha$, and PAI- 1 , and $10^{7}$ molecules of cRNA for $\beta$-actin, all in the presence of $1 \mu \mathrm{g}$ total tissue RNA and $5 \times 10^{5} \mathrm{cpm}$ of ${ }^{32} \mathrm{P}$-labeled oligonucleotide as described (Samad et al, 1996; Yamamoto and Loskutoff, 1996). Aliquots $(20 \mu \mathrm{l})$ of the PCR products were electrophoresed through $2 \%$ to $2.5 \%$ agarose gels containing ethidium bromide. The appropriate bands corresponding to the cRNA product and the target mRNA product were excised from the gel, and the incorporated radioactivity was determined using a scintillation counter. A standard curve for the cRNA was constructed and employed to extrapolate the number of molecules of target mRNA per microgram of total tissue RNA. Variations in sample loading were assessed by measuring $\beta$-actin mRNA.

\section{In Situ Hybridization}

Procedures for the preparation of all ${ }^{35} \mathrm{~S}$-labeled riboprobes and for in situ hybridization were as described previously (Yamamoto and Loskutoff, 1996). After hybridization, the slides were dehydrated by immersion in a graded alcohol series containing $0.3 \mathrm{M}$ $\mathrm{NH}_{4} \mathrm{Ac}$, dried, and either placed directly on XAR-5 film (Eastman Kodak, Rochester, New York) for regional in situ autoradiography, or coated with emulsion for high-resolution analysis. For regional autoradiography, the films were developed and photographed after incubation in the dark at room temperature for 2 weeks. For high-resolution in situ analysis, the slides were coated with NTB2 emulsion (Kodak; 1:2 in water), and exposed in the dark at $4^{\circ} \mathrm{C}$ for 4 to 8 weeks. The slides were developed for 2 minutes in D19 developer (Kodak), fixed, washed in water, and counterstained with hematoxylin and eosin. In all cases, parallel sections were analyzed using a sense probe as the control for nonspecific hybridization. No specific hybridization signal could be detected in these control hybridizations.

\section{Statistical Analysis}

Statistical analysis of all quantitative RT-PCR results was performed by using the Student's two-tailed unpaired $t$ test for comparisons between groups (Statview Software, Abacus Concepts, Berkeley, California). Differences were not considered significant when $p>0.05$ (group size, $\mathrm{n}=5$ ).

\section{Acknowledgements}

The authors thank T. Thinnes for expert technical assistance and M. McRae for excellent secretarial assistance.

\section{References}

Barnes JL, Mitchell RJ, and Torres ES (1995). Expression of plasminogen activator inhibitor-1 (PAl-1) during cellular remodeling in proliferative glomerulonephritis in the rat. J Histochem Cytochem 43:895-905.

Bassols A and Massagu J (1988). Transforming growth factor $\beta$ regulates the expression and structure of extracellular matrix chondroitin/dermatan sulfate proteoglycans. J Biol Chem 263:3039-3045.

Border WA and Noble NA (1994). Transforming growth factor $\beta$ in tissue fibrosis. N Engl J Med 331:1286-1292.

Border WA, Okuda S, Languino LR, and Ruoslahti E (1990a). Transforming growth factor $\beta$ regulates production of proteoglycans by mesangial cells. Kidney Int 37:689-695.

Border WA, Okuda S, Languino LR, Sporn MB, and Ruoslahti E (1990b). Suppression of experimental glomerulonephritis by antiserum against transforming growth factor $\beta 1$. Nature 346:371-374.

Border WA and Ruoslahti E (1992). Transforming growth factor $\beta$ in disease: The dark side of tissue repair. $J$ Clin Invest 90:1-7. 
Boswell JM, Yui MA, Burt DW, and Kelley VE (1988). Increased tumor necrosis factor and IL-1 $\beta$ gene expression in the kidneys of mice with lupus nephritis. J Immunol 141: 3050-3054.

Brennan DC, Yui MA, Wuthrich RP, and Kelley VE (1989). Tumor necrosis factor and IL-1 in New Zealand black/white mice. Enhanced gene expression and acceleration of renal injury. J Immunol 143:3470-3475.

Broekelmann TJ, Limper AH, Colby TV, and McDonald JA (1991). Transforming growth factor- $\beta 1$ is present at sites of extracellular matrix gene expression in human pulmonary fibrosis. Proc Natl Acad Sci USA 88:6642-6646.

Caver TE, O'Sullivan FX, Gold LI, and Gresham HD (1996). Intracellular demonstration of active TGF $\beta 1$ in B cells and plasma cells of autoimmune mice. IgG-bound TGF $\beta 1$ suppresses neutrophil function and host defense against Staphylococcus aureus infection. J Clin Invest 98:2496-2506.

Clauss M, Ryan J, and Stern D (1992). Modulation of endothelial cell hemostatic properties by TNF: Insights into the role of endothelium in the host response to inflammatory stimuli. In: Beutler B, editor. Tumor necrosis factors: The molecules and their emerging role in medicine. New York: Raven Press, Ltd., 49-63.

Coimbra T, Wiggins R, Noh JW, Merritt S, and Phan SH (1991). Transforming growth factor- $\beta$ production in antiglomerular basement membrane disease in the rabbit. Am J Pathol 138:223-234.

Connor TJ Jr, Roberts AB, Sporn MB, Danielpour D, Dart LL, Michels RG, de Bustros S, Enger C, Kato H, Lansing M, Hayashi $H$, and Glaser CB (1989). Correlation of fibrosis and transforming growth factor- $\beta$ type 2 levels in the eye. $\mathrm{J}$ Clin Invest 83:1661-1666.

Czaja MJ, Weiner FR, Flanders KC, Giambrone M-A, Wind R, Biempica L, and Zern MA (1989). In vitro and in vivo association of transforming growth factor- $\beta 1$ with hepatic fibrosis. J Cell Biol 108:2477-2482.

Edwards DR, Murphy G, Reynolds JJ, Whitham SE, Docherty AJP, Angel P, and Heath JK (1987). Transforming growth factor beta modulates the expression of collagenase and metalloproteinase inhibitor. EMBO J 6:1899-1904.

Eitzman DT, McCoy RD, Zheng X, Fay WP, Shen T, and Ginsburg D (1996). Bleomycin-induced pulmonary fibrosis in transgenic mice that either lack or overexpress the murine plasminogen activator inhibitor-1 gene. J Clin Invest 97:232237.

Espevik T and Nissen-Meyer J (1986). A highly sensitive cell line, WEHI 164 clone 13, for measuring cytotoxic factor/ tumor necrosis factor from human monocytes. J Immunol Methods 95:99-105.

Gomez-Chiarri M, Ortiz A, Lerma JL, Lopez-Armada MJ, Mampaso F, Gonzalez E, and Egido J (1994). Involvement of tumour necrosis factor and platelet-activating factor in the pathogenesis of experimental nephrosis in rats. Lab Invest 70:449-459.

Grainger DJ, Mosedale DE, Metcalfe JC, Weissberg PL, and Kemp PR (1995). Active and total TGF- $\beta$ in human sera, platelets, and plasma. Clin Chim Acta 235:11-31.

Hayslett JP and Kashgarian M (1993). Nephropathy of systemic lupus erythematosus. In: Schrier RW and Gottschalk CW, editors. Diseases of the kidney. Boston: Little, Brown and Company, 2019-2037.
Ignotz R and Massagu J (1986). Transforming growth factor- $\beta$ stimulates the expression of fibronectin and collagen and their incorporation into the extracellular matrix. J Biol Chem 261:4337-4345.

Jacob CO and McDevitt HO (1988). Tumor necrosis factor- $\alpha$ in murine autoimmune "lupus" nephritis. Nature 331:356358.

Kant KS, Pollak VE, and Dosekun A (1985). Lupus nephritis with thrombosis and abnormal fibrinolysis: Effect of ancrod. J Lab Clin Med 105:77-88.

Kant KS, Pollak VE, Weiss MA, Glueck HI, Miller MA, and Hess EV (1981). Glomerular thrombosis in systemic lupus erythematosus: Prevalence and significance. Medicine 60: 71-86.

Keeton M, Ahn C, Eguchi Y, Burlingame R, and Loskutoff DJ (1995). Expression of type 1 plasminogen activator inhibitor in renal tissue in murine lupus nephritis. Kidney Int 47:148157.

Keeton M, Eguchi Y, Sawdey M, Ahn C, and Loskutoff DJ (1993). Cellular localization of type 1 plasminogen activator inhibitor messenger RNA and protein in murine renal tissue. Am J Pathol 142:59-70.

Kreft B, Yokoyama H, Naito T, and Kelley VR (1996). Dysregulated transforming growth factor-beta in neonatal and adult autoimmune MRL-Ipr mice. J Autoimmun 9:463-472.

Laiho M, Saksela O, and Keski-Oja J (1987). Transforming growth factor- $\beta$ induction of type 1 plasminogen activator inhibitor. J Biol Chem 262:17467-17474.

Matsumoto K (1993). Increased release of tumor necrosis factor- $\alpha$ by monocytes from patients with glomerulonephritis. Clin Nephrol 40:148-154.

Moll S, Menoud PA, Fulpius T, Pastore Y, Takahashi S, Fossati L, Vassalli JD, Sappino AP, Schifferli JA, and Izui S (1995). Induction of plasminogen activator inhibitor type 1 in murine lupus-like glomerulonephritis. Kidney Int 48:14591468.

Neale TJ, Ruger BM, Macaulay H, Dunbar PR, Hasan Q, Bourke A, Murray-Mclntosh RP, and Kitching AR (1995). Tumor necrosis factor- $\alpha$ is expressed in glomerular visceral epithelial cells in human membranous nephropathy. Am J Pathol 146:1444-1454.

Noronha IL, Kruger C, Andrassy K, Ritz E, and Waldherr R (1993). In situ production of TNF- $\alpha, \mathrm{IL}-1 \beta$, and IL-2R in ANCA-positive glomerulonephritis. Kidney Int 43:682-692.

Okuda S, Languino LR, Ruoslahti E, and Border WA (1990). Elevated expression of transforming growth factor- $\beta$ and proteoglycan production in experimental glomerulonephritis. Possible role in expansion of the mesangial extracellular matrix. J Clin Invest 86:453-462.

Pepper MS, Montesano R, Orci L, and Vassalli J-D (1991). Plasminogen activator inhibitor-1 is induced in microvascular endothelial cells by a chondrocyte-derived transforming growth factor-beta. Biochem Biophys Res Commun 176: 633-638.

Platzer C, Richter G, Uberla K, Muller W, Blocker H, Diamantstein T, and Blankenstein T (1992). Analysis of cytokine mRNA levels in interleukin-4-transgenic mice by quantitative polymerase chain reaction. Eur J Immunol 22:1179-1184. 
Ranganathan G, Blatti SP, Subramaniam M, Fass DN, Maihle NJ, and Getz MJ (1991). Cloning of murine tissue factor and regulation of gene expression by transforming growth factor type $\beta 1$. J Biol Chem 266:496-501.

Roberts AB, Sporn MB, Assoian RK, Smith JM, Roche NS, Wakefield LM, Heine UI, Liotta LA, Falanga V, Kehrl JH, and Fauci AS (1986). Transforming growth factor type- $\beta$ : Rapid induction of fibrosis and angiogenesis in vivo and stimulation of collagen formation in vitro. Proc Natl Acad Sci USA 83:4167-4171.

Samad F, Yamamoto K, and Loskutoff DJ (1996). Distribution and regulation of plasminogen activator inhibitor-1 in murine adipose tissue in vivo: Induction by tumor necrosis factor- $\alpha$ and lipopolysaccharide. J Clin Invest 97:37-46.

Sawdey MS and Loskutoff DJ (1991). Regulation of murine type 1 plasminogen activator inhibitor gene expression in vivo: Tissue specificity and induction by lipopolysaccharide, tumor necrosis factor- $\alpha$, and transforming growth factor- $\beta$. $\mathrm{J}$ Clin Invest 88:1346-1353.

Sawdey M, Podor TJ, and Loskutoff DJ (1989). Regulation of type 1 plasminogen activator inhibitor gene expression in cultured bovine aortic endothelial cells: Induction by transforming growth factor- $\beta$, lipopolysaccharide, and tumor necrosis factor- $\alpha$. J Biol Chem 264:10396-10401.

Scarpati EM and Sadler JE (1989). Regulation of endothelial cell coagulant properties: Modulation of tissue factor, plasminogen activator inhibitors, and thrombomodulin by phorbol 12-myristate 13-acetate and tumor necrosis factor. J Biol Chem 264:20705-20713.

Schleef RR, Bevilacqua MP, Sawdey M, Gimbrone MA Jr, and Loskutoff DJ (1988). Cytokine activation of vascular endothelium: Effects on tissue-type plasminogen activator and type 1 plasminogen activator inhibitor. J Biol Chem 263:5797-5803.

Shah M, Foreman DM, and Ferguson WJ (1992). Control of scarring in adult wounds by neutralizing antibody to transforming growth factor $\beta$. Lancet 339:213-214.

Theofilopoulos AN and Dixon FJ (1985). Murine models of systemic lupus erythematosus. Adv Immunol 37:269-330.

Thompson NL, Bazoberry F, Speir EH, Casscells W, Ferrans VJ, Flanders KC, Kondaiah P, Geiser AG, and Sporn MB (1988). Transforming growth factor beta-1 in acute myocardial infarction in rats. Growth Factors 1:91-99.

Tomooka S, Border WA, Marshall BC, and Noble NA (1992). Glomerular matrix accumulation is linked to inhibition of the plasmin protease system. Kidney Int 42:1462-1469.

Tovey MG, Content J, Gresser I, Gugenheim J, Blanchard B, Guymarho J, Poupart P, Gigou M, Shaw A, and Fiers W (1988). Genes for IFN- $\beta 2$ (IL-6), tumor necrosis factor, and $\mathrm{IL}-1$ are expressed at high levels in the organs of normal individuals. J Immunol 141:3106-3110.
Tracey KJ and Cerami A (1994). Tumor necrosis factor: A pleiotropic cytokine and therapeutic target. Annu Rev Med 45:491-503.

Tsumagari T and Tanaka K (1984). Effects of fibrinogen degradation products on glomerular mesangial cells in culture. Kidney Int 26:712-718.

van Hinsbergh VW, Kooistra T, van den Berg EA, Princen HM, Fiers W, and Emeis JJ (1988). Tumor necrosis factor increases the production of plasminogen activator inhibitor in human endothelial cells in vitro and in rats in vivo. Blood 72:1467-1473.

Vassalli J-D, Sappino A-P, and Belin D (1991). The plasminogen activator/plasmin system. J Clin Invest 88:1067-1072.

Wilson HM, Reid FJ, Brown PAJ, Power DA, Haites NE, and Booth NA (1993). Effect of transforming growth factor- $\beta 1$ on plasminogen activators and plasminogen activator inhibitor-1 in renal glomerular cells. Exp Nephrol 1:343-350.

Yamamoto K and Loskutoff DJ (1996). Fibrin deposition in tissues from endotoxin-treated mice correlates with decreases in the expression of urokinase-type but not tissuetype plasminogen activator. J Clin Invest 97:2440-2451.

Yamamoto K and Loskutoff DJ (1997). The kidneys of mice with autoimmune disease acquire a hypofibrinolytic/ procoagulant state that correlates with the development of glomerulonephritis and tissue microthrombosis. Am J Pathol 151:725-734.

Yamamoto T, Nakamura T, Noble NA, Ruoslahti E, and Border WA (1993). Expression of transforming growth factor $\beta$ is elevated in human and experimental diabetic nephropathy. Proc Natl Acad Sci USA 90:1814-1818.

Yamamoto T, Noble NA, Cohen AH, Nast CC, Hishida A, and Gold LI (1996). Expression of transforming growth factor- $\beta$ isoforms in human glomerular diseases. Kidney Int 49:461469.

Yokoyama H, Kreft B, and Kelley VR (1995). Biphasic increase in circulating and renal TNF-alpha in MRL-lpr mice with differing regulatory mechanisms. Kidney Int 47:122-130.

Yoshioka K, Takemura T, Murakami K, Okada M, Hino S, Miyamoto $H$, and Maki S (1993). Transforming growth factor- $\beta$ protein and mRNA in glomeruli in normal and diseased human kidneys. Lab Invest 68:154-163. 